\title{
Biological and Genomic Characterization of a Novel Tobamovirus Infecting Hoya spp.
}

Scott Adkins, ${ }^{\dagger}$ United States Department of Agriculture, Agricultural Research Service, U.S. Horticultural Research Laboratory, Fort Pierce, FL 34945; Tom D'Elia, Kornelia Fillmer, and Patchara Pongam, Biology Department, Indian River State College, 3209 Virginia Avenue, Fort Pierce, FL 34981; and Carlye A. Baker, Florida Department of Agriculture and Consumer Services, Division of Plant Industry, Gainesville, FL 32608

\begin{abstract}
Foliar symptoms suggestive of virus infection were observed on the ornamental plant hoya (Hoya spp.; commonly known as waxflower) in Florida. An agent that reacted with commercially available tobamovirus detection reagents was mechanically transmitted to Chenopodium quinoa and Nicotiana benthamiana. Rod-shaped particles $\sim 300 \mathrm{~nm}$ in length and typical of tobamoviruses were observed in partially purified virion preparations by electron microscopy. An experimental host range was determined by mechanical inoculation with virions, and systemic infections were observed in plants in the Asclepiadaceae, Apocynaceae, and Solanaceae families. Some species in the Solanaceae and Chenopodiaceae families allowed virus replication only in inoculated leaves, and were

thus only local hosts for the virus. Tested plants in the Amaranthaceae, Apiaceae, Brassicaceae, Cucurbitaceae, Fabaceae, and Malvaceae did not support either local or systemic virus infection. The complete genome for the virus was sequenced and shown to have a typical tobamovirus organization. Comparisons of genome nucleotide sequence and individual gene deduced amino acid sequences indicate that it is a novel tobamovirus sharing the highest level of sequence identity with Streptocarpus flower break virus and members of the Brassicaceae-infecting subgroup of tobamoviruses. The virus, for which the name Hoya chlorotic spot virus (HoCSV) is proposed, was detected in multiple hoya plants from different locations in Florida.
\end{abstract}

Hoya (Hoya spp.) are climbing or twining plants native to Asia and the Pacific Islands (Bailey et al. 1976). These members of the Asclepiadaceae produce flowers with thick, wax-like petals on umbels leading to the interchangeable common names of waxflower, porcelainflower, and wax plant (Bailey et al. 1976; Stresau 1986). Leaves and plants vary in size, morphology, and color, and include variegated leaf types commonly marketed as Krimson Queen and contorted, folded, and curled leaf types commonly marketed as Indian Rope or Hindu Rope (Bailey et al. 1976; Harris 1973). These types of hoya are popular perennial outdoor plants in subtropical regions like Florida, and are often grown in hanging baskets to accentuate the vining growth habit and dangling flowers (Stresau 1986). The various types of hoya are also attractive houseplants in temperate areas (Courtier and Clarke 1997; Harris 1973).

Araujia mosaic virus, a potyvirus isolated from other members of the Asclepiadaceae, is reported to cause symptomless infections in hoya following mechanical inoculation (Charudattan et al. 1980). At least four tospoviruses are known to naturally infect several species of hoya. For instance, tomato chlorotic spot virus (TCSV) has recently been reported infecting $H$. wayetii in Florida (Baker and Adkins 2015). Tomato spotted wilt virus and Impatiens necrotic spot virus have previously been shown to infect hoya (Parrella et al. 2003 and references therein; S. Adkins, unpublished). Finally, Capsicum chlorosis virus has been detected in hoya in Hawaii and Australia (Melzer et al. 2014; Persley et al. 2006).

${ }^{\dagger}$ Corresponding author: S. Adkins; E-mail: scott.adkins@ars.usda.gov

Funding: Financial support was provided in part by The Banack Family Partnership Endowed Teaching Chairs in Agriculture to P.P. and T.D.

Disclaimer: Mention of a trademark, warranty, proprietary product, or vendor does not constitute a guarantee by the U.S. Department of Agriculture and does not imply its approval to the exclusion of other products or vendors that also may be suitable.

Accepted for publication 9 June 2018.

This article is in the public domain and not copyrightable. It may be freely reprinted with customary crediting of the source. The American Phytopathological Society, 2018.
Chlorotic spots, ringspots, and ring patterns were observed on hoya foliage by a horticultural inspector in a central Florida nursery in July 2012. Several similarly symptomatic hoya plants of the Krimson Queen and Indian Rope types were later observed in Florida home gardens. Tospoviruses were not detected in any of these plants, but all were positive when tested with commercially available tobacco mosaic virus (TMV) lateral flow immunoassay reagents (Agdia, Elkhart, IN). An agent that caused chlorotic local lesions was mechanically transmitted to Chenopodium quinoa, from which a putative tobamovirus was isolated. In this article, we present biological and genomic characterization of the putative tobamovirus, for which the name Hoya chlorotic spot virus (HoCSV) is proposed.

\section{Materials and Methods}

Virus sources and maintenance. A hoya plant with chlorotic spots, ringspots, and ring patterns was collected from a central Florida nursery in July 2012. Leaves from this plant were homogenized at a ratio of 1:10 (wt/vol) in $20 \mathrm{mM}$ sodium phosphate buffer $(\mathrm{pH} 7.0)$ containing $1 \%$ (wt/vol) Celite to mechanically inoculate $C$. quinoa. Chlorotic local lesions developed on inoculated $C$. quinoa leaves 3-5 days postinoculation and were used for mechanical transmission of HoCSV, the putative tobamovirus characterized in this report, to additional $C$. quinoa plants to increase and maintain the virus. Later in the study, mechanical inoculation of $N$. benthamiana was also used to increase and maintain HoCSV. Additional similarly symptomatic hoya plants of the Krimson Queen and Indian Rope types were observed in, and collected from, home gardens in southeastern Florida later in 2012 and early 2013.

Virion isolation and characterization. Virions were isolated from inoculated $C$. quinoa leaves or systemically infected (i.e., upper, noninoculated) $N$. benthamiana leaves following a typical tobamovirus protocol (Wetter and Conti 1988). Partially purified virion preparations were examined by electron microscopy on 300 mesh Formvar-coated copper grids after staining with 5\% (wt/vol) uranyl acetate. Measurements of representative virions were used to determine a mean particle length.

Host range determination. Mechanical inoculation of 17 plant species in 10 families was used to determine an experimental host range for HoCSV (Table 1). All plants were grown from seed except for Krimson Queen and Indian Rope hoya, and desert rose (Adenium obesum), which were propagated by cuttings from virus-free stock 
plants kept in an isolated greenhouse. Host range plants were maintained in a greenhouse under natural lighting with a daytime high temperature of $30^{\circ} \mathrm{C}$. All plants were mechanically inoculated with the HoCSV virion preparation in the phosphate buffer indicated above at the 3-5 true leaf stage and evaluated weekly for symptoms. Local and systemic infection status were determined by indirect enzymelinked immunosorbent assay (ELISA) and/or reverse transcriptionpolymerase chain reaction (RT-PCR) at 2 weeks postinoculation for annual plants and at 4 weeks postinoculation for perennial plants as described below. Hoya and desert rose plants were maintained until flowering to ascertain any effects on flower color.

Initial detection of HoCSV using commercially available TMV lateral flow immunoassay reagents suggested that production of a specific HoCSV antiserum might not be necessary. Indirect ELISA using commercially available TMV antiserum (Agdia) was found to be suitable for HoCSV detection. Two samples were collected from each plant: one from an inoculated leaf, and a second from an upper, noninoculated leaf. Briefly, leaf tissue was homogenized at a ratio of 1:10 (wt/vol) in commercially available coating buffer (Agdia), loaded in polystyrene plates $(100 \mu \mathrm{l} /$ well), and incubated overnight at $4{ }^{\circ} \mathrm{C}$. The following morning, plates were washed three times with phosphate-buffered saline (PBS; $0.14 \mathrm{M} \mathrm{NaCl}, 1 \mathrm{mM}$ $\mathrm{KH}_{2} \mathrm{PO}_{4}, 8 \mathrm{mM} \mathrm{Na} 2 \mathrm{HPO}_{4}, 2.5 \mathrm{mM} \mathrm{KCl}$ [pH 7.4]) containing $0.5 \%$ (vol/vol) Tween 20 (PBST). TMV antiserum (Agdia) diluted $1: 100$ ( vol/vol) in PBST was incubated $(100 \mu \mathrm{l} / \mathrm{well})$ for $3 \mathrm{~h}$ at $37^{\circ} \mathrm{C}$. Plates were washed again as above, and alkaline phosphatase conjugated goat anti-rabbit secondary antibody (Bio-Rad, Hercules, CA) diluted 1:3,000 (vol/vol) in PBST was incubated $(100 \mu \mathrm{l} /$ well) for $3 \mathrm{~h}$ at $37^{\circ} \mathrm{C}$. After a final rinse, $p$-nitrophenyl phosphate was added, and $405 \mathrm{~nm}$ absorbance $\left(A_{405} \mathrm{~nm}\right)$ readings were measured after a 1.5 to $2 \mathrm{~h}$ room temperature incubation. Controls of noninfected leaves, coating buffer only, and infected leaves from original HoCSV source plants were included in all assays. Two wells were used for each sample with the mean becoming the $A_{405 \mathrm{~nm}}$ reading for the sample. A threshold value for positive samples was set at twice the $A_{405} \mathrm{~nm}$ reading of the noninfected control leaves.

All samples from species testing negative by ELISA, and representative samples from species testing positive by ELISA, were further examined by RT-PCR for HoCSV. Since the full genome of HoCSV was not yet determined at the time of experimental host range studies, we used degenerate tobamovirus primers tob4404v (5'-GGDGAYGTNACNACNTTYATHGG-3') and tob4593vc (5' ANARYTTNGCYTCRAARTTCC-3') designed as part of this study to amplify $200 \mathrm{nt}$ of the RNA-dependent RNA polymerase (RdRp) gene of currently recognized tobamoviruses. RNA was extracted using Trizol reagent (Invitrogen, Carlsbad, CA) from inoculated and upper, noninoculated leaves for each plant. First-strand cDNA was synthesized by Moloney murine leukemia virus reverse transcriptase (Promega, Madison, WI) using random hexamers (Roche, Indianapolis, IN) at $45^{\circ} \mathrm{C}$ for 45 min with standard methods (Sambrook and Russell 2001). This was followed by PCR amplification with Taq polymerase (Promega) at $94^{\circ} \mathrm{C}$ for $1 \mathrm{~min}, 30$ cycles of $94^{\circ} \mathrm{C}$ for $30 \mathrm{~s}$, $55^{\circ} \mathrm{C}$ for $45 \mathrm{~s}$, and $72^{\circ} \mathrm{C}$ for $45 \mathrm{~s}$, and finally $72^{\circ} \mathrm{C}$ for $10 \mathrm{~min}$ using tob4404v and tob4593vc primers.

Sequencing and analysis of HoCSV genome. HoCSV genomic RNA was prepared with Trizol reagent from virions isolated from locally infected $C$. quinoa leaves (Sanger sequencing) or systemically infected $N$. benthamiana leaves (Ion Torrent sequencing). Initial HoCSV sequence (within the RdRp gene) was developed by use of the degenerate tobamovirus primers indicated above. Five clones were sequenced in both directions on an ABI 3730XL automated sequencer at the USHRL DNA Sequencing Support Laboratory. Sequences were edited in VectorNTI (ThermoFisher Scientific, Carlsbad, $\mathrm{CA}$ ), and additional primers were designed from this sequence to

Table 1. Plant species used to establish experimental host range and symptoms of Hoya chlorotic spot virus (HoCSV)

\begin{tabular}{|c|c|c|c|c|}
\hline \multirow[b]{2}{*}{ Family, species, and cultivar ${ }^{a}$} & \multirow[b]{2}{*}{ Common name } & \multirow[b]{2}{*}{ HoCSV symptoms ${ }^{b}$} & \multicolumn{2}{|c|}{ HoCSV infection ${ }^{c}$} \\
\hline & & & Local & Systemic \\
\hline \multicolumn{5}{|l|}{ Amaranthaceae } \\
\hline Gomphrena globosa 'Strawberry Fields' & Globe amaranth & $-1-$ & 0 of 10 & 0 of 10 \\
\hline \multicolumn{5}{|l|}{ Apiaceae } \\
\hline Coriandrum sativum & Coriander & $-1-$ & 0 of 10 & 0 of 10 \\
\hline \multicolumn{5}{|l|}{ Apocynaceae } \\
\hline Adenium obesum & Desert rose & $\mathrm{M}, \mathrm{RS} / \mathrm{M}, \mathrm{FB}$ & 9 of 10 & 8 of 10 \\
\hline \multicolumn{5}{|l|}{ Asclepiadaceae } \\
\hline Hoya spp. Krimson Queen & Hoya & CL,RS/CL,RS & 11 of 11 & 11 of 11 \\
\hline Hoya spp. Indian Rope & Hoya & CL/CL,NL & 10 of 10 & 10 of 10 \\
\hline \multicolumn{5}{|l|}{ Brassicaceae } \\
\hline Brassica oleracea 'Farao' & Cabbage & $-1-$ & 0 of 10 & 0 of 10 \\
\hline \multicolumn{5}{|l|}{ Chenopodiaceae } \\
\hline Chenopodium quinoa & Lambsquarters & CLL/- & 10 of 10 & 0 of 10 \\
\hline \multicolumn{5}{|l|}{ Cucurbitaceae } \\
\hline Cucumis sativus 'Straight Eight' & Cucumber & $-1-$ & 0 of 10 & 0 of 10 \\
\hline \multicolumn{5}{|l|}{ Fabaceae } \\
\hline Phaseolus vulgaris 'Caprice' & Green bean & $-1-$ & 0 of 10 & 0 of 10 \\
\hline \multicolumn{5}{|l|}{ Malvaceae } \\
\hline Gossypium hirsutum 'DP1044B2RF' & Cotton & $-1-$ & 0 of 10 & 0 of 10 \\
\hline \multicolumn{5}{|l|}{ Solanaceae } \\
\hline Capsicum апnиит 'Aristotle' & Bell pepper & $-1-$ & 0 of 10 & 0 of 10 \\
\hline Datura stramonium & Jimsonweed & NLL/- & 9 of 10 & 0 of 10 \\
\hline Nicotiana benthamiana & & M,VC/LD & 4 of 10 & 10 of 10 \\
\hline N. rustica & & $-1-$ & 0 of 10 & 0 of 10 \\
\hline N. sylvestris & & $-1-$ & 0 of 10 & 0 of 10 \\
\hline Petunia $\times$ hybrida 'Red Supercascade' & Petunia & NLL/- & 10 of 10 & 0 of 10 \\
\hline Solanum americanum & American black nightshade & $-1-$ & 0 of 10 & 0 of 10 \\
\hline S. lycopersicum 'Florida 47' & Tomato & $-1-$ & 0 of 10 & 0 of 10 \\
\hline
\end{tabular}


"walk" toward the 3' terminus of the genome by Sanger sequencing (Sambrook and Russell 2001). The movement protein (MP) and coat protein $(\mathrm{CP})$ genes, and much of the $3^{\prime}$-nontranslated region (NTR), were obtained in this manner.

Subsequently, a cDNA library was prepared using Ion Total RNASeq v2 and Ion Xpress RNA-Seq Barcode kits (ThermoFisher Scientific) and sequenced using an Ion PGM Template OT2 200 kit with an Ion 314 chip on an Ion Torrent Personal Genome Machine (ThermoFisher Scientific) following the manufacturer's protocols. Raw data were processed with the Torrent Suite software v. 4.0 (ThermoFisher Scientific) to generate the FASTQ sequences for assembly. CLC Genomics Workbench v. 8.5.1 (Qiagen, Redwood City, CA) was used for de novo assembly of 5,979 nt of the HoCSV genome that was used for further primer design and "walking" by Sanger sequencing. The 5' terminus was determined with $5^{\prime}$ RACE using a primer designed from the initial genome sequence and a SMARTer RACE 5'/3' kit (Takara Bio, Mountain View, CA). The initial genome sequence was extended using Geneious v. R8 (8.1.4; Biomatters, Auckland, New Zealand). Ion Torrent reads were mapped to the de novo assembly, and Sanger reads were added to fill gaps. Several iterations of this process yielded the complete 6,386 nt HoCSV genome (GenBank accession no. KX434725).

Sequence and phylogenetic analyses were made using MEGA6 (Tamura et al. 2013). Nucleotide and deduced amino acid sequences of HoCSV and recognized tobamoviruses were used to generate multiple sequence alignments with ClustalW (Thompson et al. 1994). Neighbor-joining phylogenetic trees were constructed using the pdistance substitution model and 1,000 bootstrap replicates. Pairwise comparisons of HoCSV and recognized tobamoviruses were made with Sequence Demarcation Tool (SDT) using the default parameters (Muhire et al. 2014).
Development of HoCSV-specific RT-PCR assay. With the complete HoCSV genome sequence available, primers were designed by comparison with recognized tobamovirus species to specifically amplify the HoCSV CP gene. The viral sense primer HoCSV_CPv (5'CCGCAATCAATGGTGTACCAAATC-3') is identical to nucleotides 5705 to 5728 at the start of the deduced $\mathrm{CP}$ gene, and the viral complementary sense primer HoCSV_CPvc (5'-CAGACCATCC GAGCGGTGAAAGAC- $3^{\prime}$ ) is complementary to nucleotides 6278 to 6301 in the $3^{\prime}$-NTR. After reverse transcription as described above, these primers were used to amplify 597 bp including the $\mathrm{CP}$ gene by PCR with Taq polymerase (Promega) at $94^{\circ} \mathrm{C}$ for $1 \mathrm{~min}, 30$ cycles of $94^{\circ} \mathrm{C}$ for $30 \mathrm{~s}, 60^{\circ} \mathrm{C}$ for $45 \mathrm{~s}, 72^{\circ} \mathrm{C}$ for $45 \mathrm{~s}$, and finally $72^{\circ} \mathrm{C}$ for $10 \mathrm{~min}$. Following sequence confirmation that the amplicon contained the HoCSV CP gene, specificity of the primers for HoCSV was investigated by testing eight recognized tobamoviruses (Hibiscus latent Fort Pierce virus [HLFPV], Hibiscus latent Singapore virus [HLSV], pepper mild mottle virus [PMMoV], sunn-hemp mosaic virus [SHMV], tobacco mild green mosaic virus [TMGMV], TMV, tomato mottle mosaic virus [ToMMV], and tropical soda apple mosaic virus [TSAMV]) representing Malvaceae-, Solanaceae-, and Fabaceaeinfecting subgroups. Total RNA from eight independent plants, each infected with one of these eight tobamoviruses, was extracted with Trizol and tested by RT-PCR with HoCSV_CPv/vc primers and degenerate tobamovirus primers tob4404v/tob4593vc as described above. RT-PCR products were analyzed by electrophoresis on $1 \%$ agarose (wt/vol) gels.

\section{Results}

Isolation and characterization of HoCSV. Virions were isolated from both inoculated C. quinoa leaves and systemically infected $N$. benthamiana leaves from plants inoculated with leaves from the
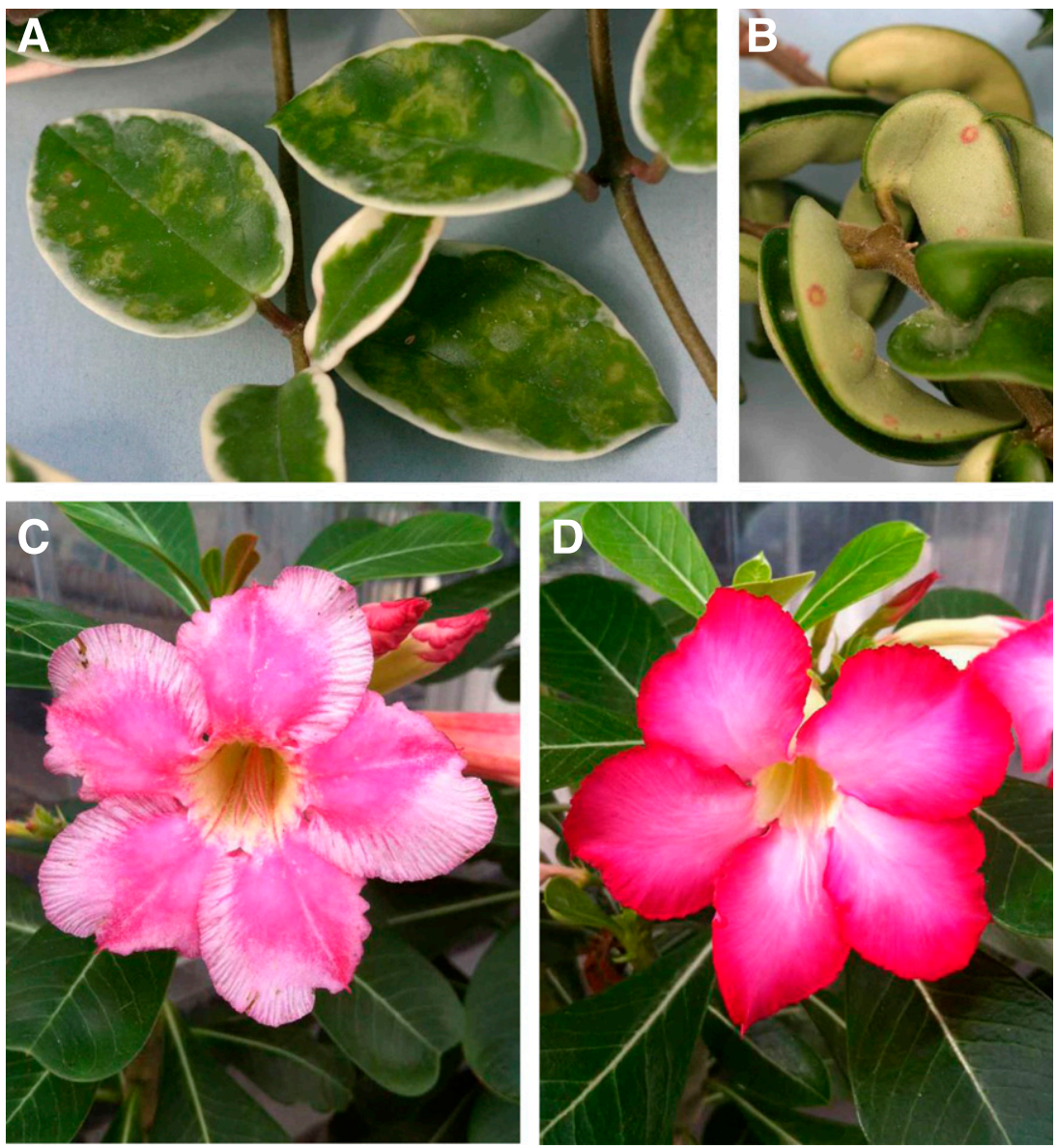

Fig. 1. Symptoms of Hoya chlorotic spot virus (HoCSV) infection following mechanical inoculation. Systemically infected (i.e., upper, noninoculated) leaves of hoya A, Krimson Queen and B, Indian Rope showing diffuse chlorotic spots/ringspots or necrotic ringspots, respectively. C, Color breaking in desert rose flower on HoCSV-infected plant. D, Desert rose flower from mock inoculated (i.e., noninfected) plant of the same type shown for comparison. 
original hoya plant collected in July 2012. Electron microscopy of partially purified virions revealed rigid, rod-shaped particles of $\sim 300 \mathrm{~nm}$ in length that were typical of those described for tobamoviruses. Virus-free Krimson Queen and Indian Rope hoya plants were mechanically inoculated with HoCSV virion preparations reproducing the symptoms observed in the original plant. Chlorotic spots appeared on inoculated leaves of both hoya types 10-14 days postinoculation. Chlorotic spots, ringspots, and/or ring patterns appeared on systemically infected leaves of Krimson Queen (Fig. 1A) and Indian Rope within a month. Careful observation of Indian Rope was required because the earliest symptoms were on the adaxial leaf surfaces and located within the folded and curled leaves. However, by 2 months postinoculation, necrotic ringspots were obvious on the abaxial leaf surfaces and easily observed (Fig. 1B). Foliar symptoms continued to appear in newly emerged leaves of both Krimson Queen and Indian Rope for 5 years. No change in flower color was observed in either type of hoya. Testing of mechanically inoculated Krimson Queen and Indian Rope plants with indirect ELISA and RT-PCR as described above confirmed the presence of HoCSV. Identical results were obtained with subsequent home garden collections of both Krimson Queen and Indian Rope. No symptom or sequence differences were observed from the initial HoCSV isolate, so it was used for all further experiments.
Host range determination. An experimental host range was determined for HoCSV by mechanical inoculation of 17 species in 10 families (Table 1), including hosts reported for members of most tobamovirus subgroups. Systemic infection was observed in both tested members of the Asclepiadaceae (Krimson Queen and Indian Rope hoya) as noted above (Fig. 1A and B). Systemic infection was also observed in the tested Apocynaceae species (desert rose, A. obesum) with an initial mild mosaic and ringspots on leaves that faded over time, and a later striking color break of flowers (Fig. $1 \mathrm{C}$ and D). Chlorotic local lesions developed on inoculated leaves of the tested Chenopodiaceae species (C. quinoa). Necrotic local lesions developed on inoculated leaves of two tested Solanaceae species (Datura stramonium and Petunia $\times$ hybrida). Systemic infection was observed in only one tested Solanaceae species ( $N$. benthamiana). No infection was detected in any of the other five Solanaceae species tested, including the commercially important vegetable crops pepper (Capsicum annuum) and tomato (Solanum lycopersicum). No evidence of infection was detected in any of the inoculated Amaranthaceae, Apiaceae, Brassicaceae, Cucurbitaceae, Fabaceae, or Malvaceae species, including several common virus indicator hosts.

HoCSV genome sequence analysis. The complete genome of HoCSV was determined to be 6,386 nt (GenBank accession no. KX434725). The genome organization was typical of recognized

Table 2. Percent identity of nucleotide (nt) sequences for complete genome, and deduced amino acid (aa) sequences for the 181-189 kDa RNA-dependent RNA polymerase (RdRp), movement (MP), and coat (CP) proteins of Hoya chlorotic spot virus (HoCSV) and recognized tobamoviruses

\begin{tabular}{|c|c|c|c|c|c|}
\hline Tobamovirus & Genome (nt) & RdRp (aa) & MP (aa) & $\mathbf{C P}(\mathbf{a a})$ & GenBank $^{\mathbf{a}}$ \\
\hline Bell pepper mottle virus (BpeMV) & 63.4 & 60.6 & 37.8 & 48.1 & NC_009642 \\
\hline Brugmansia mild mottle virus (BrMMV) & 62.9 & 60.0 & 36.6 & 47.1 & NC_010944 \\
\hline Cactus mild mosaic virus $(\mathrm{CMMoV})$ & 59.0 & 44.0 & 27.1 & 34.0 & NC_011803 \\
\hline Clitoria yellow mottle virus (CIYMV) & 58.4 & 44.1 & 24.4 & 35.8 & NC_016519 \\
\hline $\begin{array}{l}\text { Cucumber fruit mottle mosaic virus } \\
\text { (CFMMV) }\end{array}$ & 59.7 & 45.6 & 39.4 & 34.0 & NC_002633 \\
\hline $\begin{array}{l}\text { Cucumber green mottle mosaic virus } \\
\text { (CGMMV) }\end{array}$ & 58.4 & 45.7 & 38.1 & 40.3 & NC_001801 \\
\hline Cucumber mottle virus $(\mathrm{CMoV})$ & 58.1 & 45.8 & 33.7 & 33.3 & NC_008614 \\
\hline Frangipani mosaic virus (FrMV) & 59.1 & 45.3 & 30.7 & 43.4 & NC_014546 \\
\hline Hibiscus latent Fort Pierce virus (HLFPV) & 58.9 & 49.2 & 26.1 & 43.0 & NC_025381.1 \\
\hline Hibiscus latent Singapore virus (HLSV) & 59.3 & 50.0 & 28.8 & 42.1 & NC_008310.2 \\
\hline Kyuri green mottle mosaic virus (KGMMV) & 58.7 & 45.5 & 38.8 & 32.7 & NC_003610.1 \\
\hline Maracuja mosaic virus (MarMV) & 60.9 & $-\mathrm{b}$ & 29.1 & 44.3 & NC_008716 \\
\hline Obuda pepper virus (ObPV) & 62.4 & 60.2 & 40.4 & 44.6 & NC_003852 \\
\hline Odontoglossum ringspot virus (ORSV) & 63.6 & 62.8 & 36.8 & 48.1 & NC_001728 \\
\hline Paprika mild mottle virus (PaMMV) & 62.0 & 58.9 & 41.6 & 44.6 & NC_004106 \\
\hline Passion fruit mosaic virus (PafMV) & 59.6 & 47.2 & 28.2 & 42.4 & NC_015552 \\
\hline Pepper mild mottle virus (PMMoV) & 63.2 & 59.9 & 42.5 & 45.2 & NC_003630 \\
\hline $\begin{array}{l}\text { Rattail cactus necrosis-associated virus } \\
\text { (RCNaV) }\end{array}$ & 58.8 & 43.6 & 25.3 & 37.1 & JF729471 \\
\hline Rehmannia mosaic virus (RheMV) & 62.3 & 60.9 & 38.5 & 45.2 & AB628188 \\
\hline Ribgrass mosaic virus (RMV) & 62.1 & 63.2 & 44.4 & 58.0 & NC_002792.2 \\
\hline Streptocarpus flower break virus (SFBV) & 64.0 & 63.2 & 46.0 & 54.5 & NC_008365 \\
\hline Sunn-hemp mosaic virus (SHMV) & - & 44.6 & 27.8 & 36.5 & $\begin{array}{l}\text { P89202.2 } \\
\text { P03581.2 } \\
\text { P03585.1 }\end{array}$ \\
\hline Tobacco latent virus (TLV) & - & - & 38.9 & 49.0 & AY137775 \\
\hline Tobacco mild green mosaic virus (TMGMV) & 63.5 & 62.5 & 40.3 & 43.6 & NC_001556 \\
\hline Tobacco mosaic virus (TMV) & 62.5 & 60.7 & 35.9 & 45.9 & NC_001367 \\
\hline Tomato mosaic virus (ToMV) & 63.3 & 61.1 & 39.3 & 45.2 & KR537870.1 \\
\hline Tomato mottle mosaic virus (ToMMV) & 63.6 & 60.7 & 40.4 & 47.8 & KP202857 \\
\hline Tropical soda apple mosaic virus (TSAMV) & 62.9 & 59.7 & 42.5 & 46.2 & KU659022 \\
\hline Turnip vein clearing virus (TVCV) & 62.5 & 62.7 & 49.2 & 56.1 & NC_001873 \\
\hline Wasabi mottle virus (WMoV) & 62.4 & 62.5 & 46.2 & 53.5 & NC_003355 \\
\hline $\begin{array}{l}\text { Yellow tailflower mild mottle virus } \\
\text { (YTMMV) }\end{array}$ & 63.0 & 60.5 & 43.3 & 45.5 & KF495564 \\
\hline Youcai mosaic virus (YoMV) & 63.7 & 63.3 & 45.6 & 55.4 & NC_004422 \\
\hline $\begin{array}{l}\text { Zucchini green mottle mosaic virus } \\
\text { (ZGMMV) }\end{array}$ & 58.8 & 45.5 & 39.0 & 31.4 & NC_003878 \\
\hline
\end{tabular}

\footnotetext{
${ }^{a}$ GenBank accession numbers for sequences of tobamovirus species and strains used for comparison with HoCSV (KX434725).
}

$\mathrm{b}_{-}=$incomplete genome sequence data available. 
tobamoviruses and included a $5^{\prime}$-NTR (nt 1-67), genes encoding a 183-kDa RdRp (nt 68-4915), a 126-kDa methyltransferase/helicase (nt 68-3397), MP (nt 4885-5799), and CP (nt 5714-6193), and a $3^{\prime}$-NTR (nt 6194-6386). Comparison of the complete genome sequence of HoCSV with those of recognized tobamoviruses showed sequence identities ranging from 58.1 to $64.0 \%$ (Table 2). Streptocarpus flower break virus (SFBV) was the most closely related tobamovirus, followed by members of the Solanaceae- and Brassicaceaeinfecting subgroups. Most disparate was cucumber mottle virus (CMoV) followed by members of the Cucurbitaceae-infecting
A

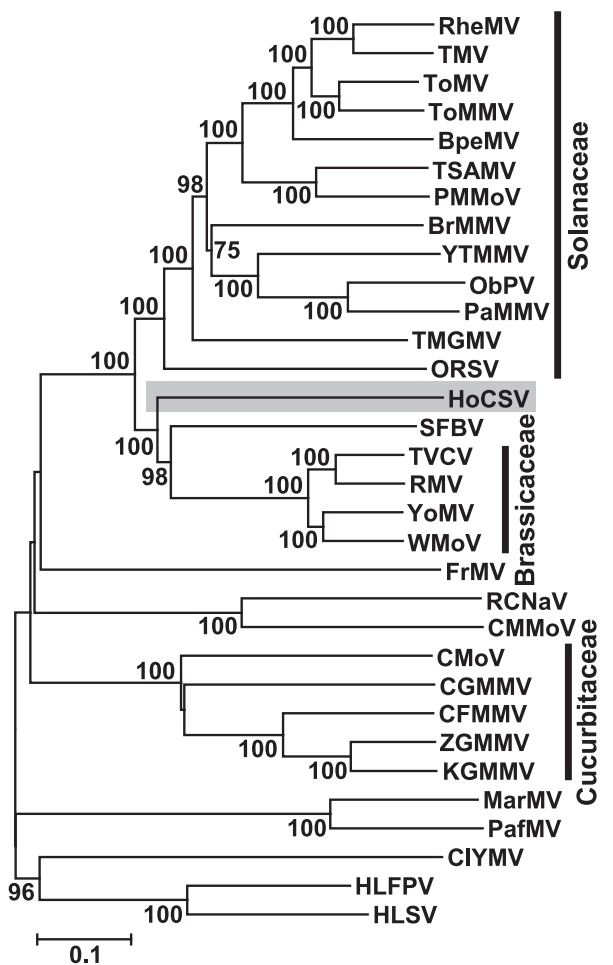

C

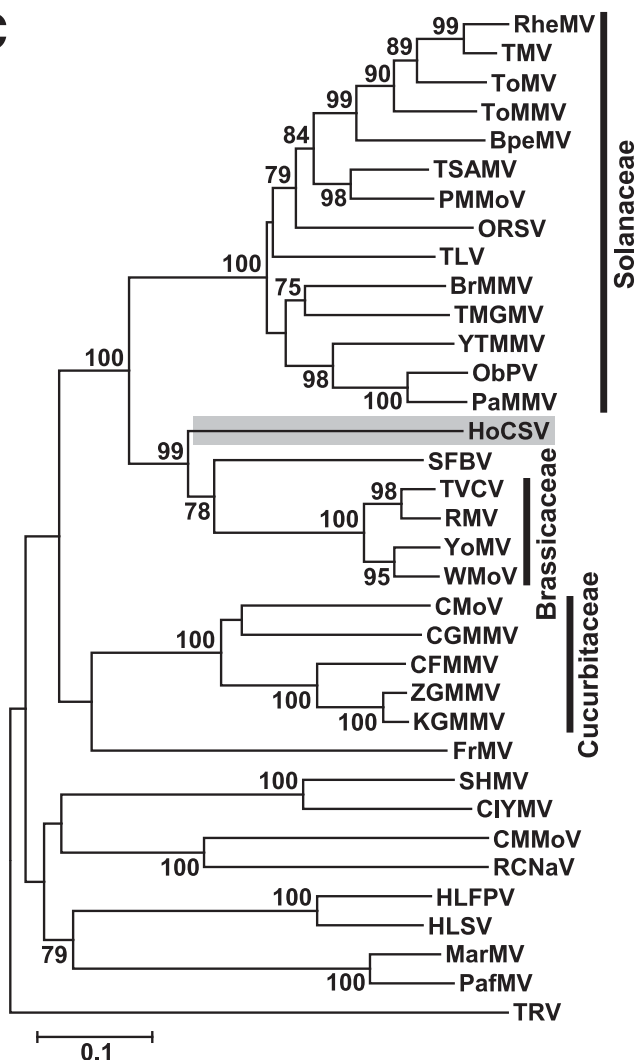

B

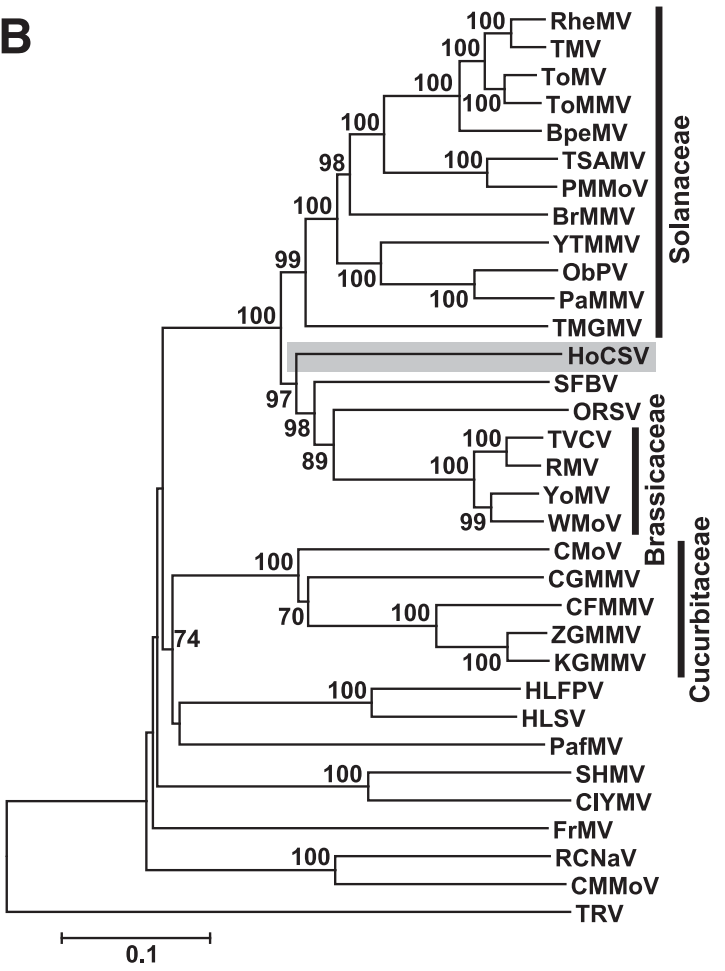

D

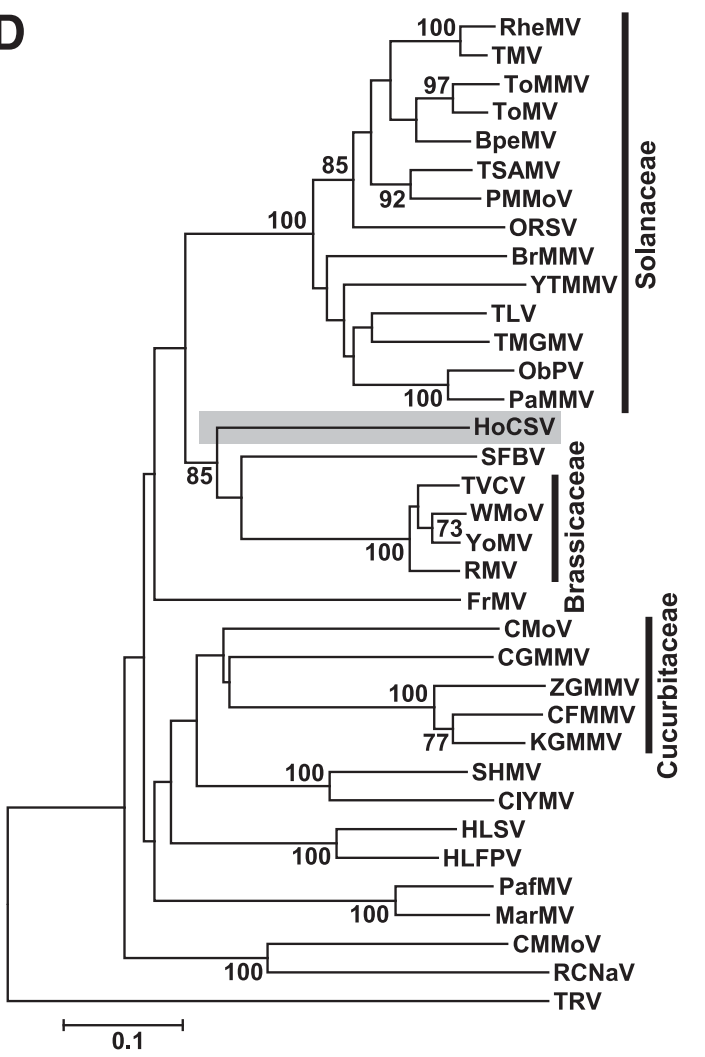

Fig. 2. Phylogenetic analysis of Hoya chlorotic spot virus (HoCSV; KX434725) and recognized species in the genus Tobamovirus based on A, complete genome nucleotide sequence, and deduced amino acid sequences of B, 181-189 kDa RNA-dependent RNA polymerase, C, movement, and D, coat proteins. Unrooted, neighbor-joining trees were inferred using MEGA6 version (Tamura et al. 2013), with tobacco rattle virus (TRV; NP_620669.2, NP_620671.1, and NP_620672.1) as an outgroup in B, C, and D. Branch lengths indicate the number of nucleotide or amino acid differences per site, and numbers at nodes indicate bootstrap values greater than 70 based on bootstrap analysis of 1,000 replicates. Tobamovirus names, abbreviations, and GenBank accession numbers for nucleotide sequences used for analysis as shown in Table 2. 
subgroup, Fabaceae-infecting Clitoria yellow mottle virus (ClYMV), and Cactaceae-infecting rattail cactus necrosis-associated virus ( $\mathrm{RCNaV})$.

Comparison of the HoCSV RdRp, MP, and CP deduced amino acid sequences with those of recognized tobamoviruses showed sequence identities ranging from 43.6 to $63.3 \%, 24.4$ to $49.2 \%$, and 31.4 to $58.0 \%$, respectively (Table 2 ). Across all three proteins, HoCSV shared highest deduced amino acid identity with members of the Brassicaceae-infecting subgroup and SFBV. The HoCSV RdRp shared highest deduced amino acid identity with youcai mosaic virus (YoMV; 63.3\%), followed by ribgrass mosaic virus (RMV) and SFBV $(63.2 \%)$, and the other two members of the Brassicaceae-infecting subgroup (turnip vein clearing virus [TVCV; 62.7\%]; wasabi mottle virus [WMoV; 62.5\%]). Odontoglossum ringspot virus (ORSV) and many members of the Solanaceae-infecting subgroup also had RdRp amino acid identities with HoCSV in the low $60 \%$ range. The HoCSV MP shared highest deduced amino acid identity with TVCV (49.2\%), all other members of the Brassicaceae-infecting subgroup (44.4-46.2\%), and SFBV (46.0\%). The HoCSV CP shared highest deduced amino acid identity with RMV (58.0\%), all other members of the Brassicaceae-infecting subgroup (53.5-56.1\%), and SFBV (54.5\%). In contrast, the HoCSV RdRp, MP, and CP deduced amino acid sequences shared the lowest identities with members of the Cactaceae-, Fabaceae-, Cucurbitaceae-, and Malvaceae-infecting subgroups.

Phylogenetic analysis of the complete genome nucleotide sequence (Fig. 2A), and the RdRp, MP, and CP deduced amino acid sequences (Fig. 2B-D), revealed previously demonstrated tobamovirus subgroups that mirror the phylogenetic grouping of the plant hosts. This includes the previously identified large Solanaceae-, Brassicaceae-, and Cucurbitaceae-infecting subgroups, and smaller clusters with only a few members (e.g., Cactaceae-, Fabaceae-, or Malvaceae-infecting tobamoviruses) (Adams et al. 2012; Adkins et al. 2003, 2007; Fillmer et al. 2016; Gibbs 1999; Kumar et al. 2015). In all analyses, HoCSV was grouped most closely with SFBV and the Brassicaceae-infecting subgroup.

Detection of HoCSV CP gene by RT-PCR. Using total RNA extracted from HoCSV-infected plants, RT-PCR with HoCSV_ $\mathrm{CPv} / \mathrm{vc}$ primers yielded amplicons of the expected size of $597 \mathrm{bp}$ as observed in agarose gels. No amplicons were obtained from total RNA extracted from non-HoCSV-infected plants, including nonsymptomatic hoya and TCSV-infected hoya. Similarly, no amplicons were produced from total RNA extracted from plants infected with any of the other eight tested tobamoviruses (HLFPV, HLSV, PMMoV, SHMV, TMGMV, TMV, ToMMV, or TSAMV). All eight of these tobamoviruses yielded amplicons of the expected size with degenerate tobamovirus primers tob4404v/tob4593vc, indicating that suitable template was available in the HoCSV_CPv/vc primer tests.

\section{Discussion}

Based on the results of this study, HoCSV appears to be a novel tobamovirus. Partially purified virions had typical tobamovirus morphology and induced symptoms following mechanical inoculation of hoya Krimson Queen and Indian Rope (Fig. 1A and B) reminiscent of the originally observed symptoms. Local lesions induced on C. quinoa, D. stramonium, and $P . \times$ hybrida (Table 1 ) were consistent with previous descriptions of other novel tobamoviruses (e.g., Adkins et al. 2003, 2007). The genome organization of HoCSV matches those of recognized tobamoviruses complete with a gene for the expected $183-\mathrm{kDa} \mathrm{RdRp}$ produced by readthrough of a leaky stop codon in the gene for a $126-\mathrm{kDa}$ methyltransferase/helicase. The only significant sequence similarity with the HoCSV genome and individual genes detected by BLAST analysis (Altschul et al. 1990) of GenBank was with recognized tobamovirus species. Pairwise comparisons of complete genome nucleotide and deduced amino acid sequences showed most similarity with members of the Brassicaceaeinfecting subgroup and SFBV (Table 2). However, the maximum nucleotide identity of $64.0 \%$ for the complete genome, and the maximum amino acid identities of $63.3,49.2$, and $58.0 \%$ for the RdRp, $\mathrm{MP}$, and $\mathrm{CP}$, respectively, are sufficient for HoCSV to be proposed as a new tobamovirus species. Placement of HoCSV at the base of the SFBV and the Brassicaceae-infecting subgroup branch (Fig. 2) indicates that HoCSV is most closely related to, but distinct from, SFBV. Curiously, although HoCSV systemically infected desert rose, the sole member of the Apocynaceae we examined (Table 1), HoCSV was not closely related to frangipani mosaic virus (FrMV; Table 2; Fig. 2), a tobamovirus isolated from Plumeria spp. (commonly known as frangipani), another member of the Apocynaceae. To date, the ability of FrMV to infect hoya or any other members of the Asclepiadaceae does not appear to have been examined (Kumar et al. 2015). This is of interest because some taxonomists consider that the Asclepiadaceae falls within the Apocynaceae, although the taxonomic authority we used (USDA PLANTS database; http://plants.usda.gov, accessed May 26, 2017) maintains them as separate families.

The experimental host range determined for HoCSV appears rather limited (Table 1). The only important crop species systemically infected were hoya (both types tested) and desert rose. This is significant because both of these ornamental crops are propagated vegetatively, making maintenance of virus-free stock plants and sanitation key for successful production as has been demonstrated for similarly produced crops like hibiscus and petunia (Kamenova and Adkins 2004; Lewandowski et al. 2010). Our detection of HoCSV in multiple hoya plants from different locations and sources within Florida suggests that this new virus may be widely distributed, although broader geographic testing is warranted. The HoCSV CP primers developed and validated as part of this research provide a specific diagnostic test for this newly described tobamovirus. RTPCR with these primers can be used to screen hoya germplasm collections and stock plants to index for HoCSV. This approach should also be useful for other HoCSV-susceptible vegetatively propagated species like desert rose. Nonspecific testing with commercially available TMV diagnostic reagents as demonstrated in this report may also be useful for initial identification of tobamovirus infections.

To our knowledge, HoCSV is the first tobamovirus reported from hoya or any other member of the Asclepiadaceae. More than a century has elapsed since the discovery of TMV (Scholthof et al. 2011), yet descriptions of new tobamoviruses in diverse plant families (e.g., Adkins et al. 2003; Kim et al. 2012; Srinivasan et al. 2005) remain common. This demonstrates the continuing relevance of tobamoviruses for growers, regulators, and the agricultural industry.

\section{Acknowledgments}

We thank Carrie Vanderspool, Jason Skaryd, Shelby Hanson, Reid Lewis, Jeff Smith, Shannon Douds, Kenneth Sims, Wayne Hunter, Ric Stange, Megan Carroll, and Yaowapa Tantiwanich for their excellent technical assistance.

\section{Literature Cited}

Adams, M. J., Heinze, C., Jackson, A. O., Kreuze, J. F., Macfarlane, S. A., and Torrance, L. 2012. Tobamovirus. Pages 1153-1156 in: Virus Taxonomy: Ninth Report of the International Committee on Taxonomy of Viruses. A. M. Q. King, M. J. Adams, E. B. Carstens, and E. J. Lefkowitz, eds. Elsevier/ Academic Press, London.

Adkins, S., Kamenova, I., Achor, D., and Lewandowski, D. J. 2003. Biological and molecular characterization of a novel tobamovirus with a unique host range. Plant Dis. 87:1190-1196.

Adkins, S., Kamenova, I., Rooskopf, E. N., and Lewandowski, D. J. 2007. Identification and characterization of a novel tobamovirus from tropical soda apple in Florida. Plant Dis. 91:287-293.

Altschul, S. F., Gish, W., Miller, W., Myers, E. W., and Lipman, D. J. 1990. Basic local alignment search tool. J. Mol. Biol. 215:403-410.

Bailey, L. H., Bailey, E. Z, and Staff of the Liberty Hyde Bailey Hortorium. 1976. Hortus Third: A Concise Dictionary of Plants Cultivated in the United States and Canada. Macmillan, New York.

Baker, C. A., and Adkins, S. 2015. First report of Tomato chlorotic spot virus in Hoya wayetii and Schlumbergera truncata. Plant Health Prog. 16:29-30.

Charudattan, R., Zettler, F. W., Cordo, H. A., and Christie, R. G. 1980. Partial characterization of a potyvirus infecting the milkweed vine, Morrenia odorata Phytopathology 70:909-913.

Courtier, J., and Clarke, G. 1997. Indoor Plants: The Essential Guide to Choosing and Caring for Houseplants. Reader's Digest, New York.

Fillmer, K., Adkins, S., Pongam, P., and D'Elia, T. 2016. The complete nucleotide sequence and genomic characterization of tropical soda apple mosaic virus. Arch. Virol. 161:2317-2320.

Gibbs, A. 1999. Evolution and origin of tobamoviruses. Philos. Trans. R. Soc. Lond., B 354:593-602. 
Harris, C. C. 1973. House Plants and Indoor Gardening. Octopus Books, London. Kamenova, I., and Adkins, S. 2004. Transmission, in planta distribution, and management of Hibiscus latent Fort Pierce virus, a novel tobamovirus isolated from Florida hibiscus. Plant Dis. 88:674-679.

Kim, N. R., Hong, J. S., Song, Y. S., Chung, B. N., Park, J. W., and Ryu, K. H. 2012. The complete genome sequence of a member of a new species of tobamovirus (rattail cactus necrosis-associated virus) isolated from Aporcactus flagelliformis. Arch. Virol. 157:185-187.

Kumar, A., Solanki, V., Verma, H. N., and Mandal, B. 2015. Characterisation and diagnosis of frangipani mosaic virus from India. Virus Genes 51:310-314.

Lewandowski, D. J., Hayes, A. J., and Adkins, S. 2010. Surprising results from a search for effective disinfectants for Tobacco mosaic virus-contaminated tools. Plant Dis. 94:542-550.

Melzer, M. J., Shimabukuro, J., Long, M. H., Nelson, S. C., Alvarez, A. M., Borth, W. B., and Hu, J. S. 2014. First report of Capsicum chlorosis virus infecting waxflower (Hoya calycina Schlecter) in the United States. Plant Dis. 98:571.

Muhire, B. M., Varsani, A., and Martin, D. P. 2014. SDT: A virus classification tool based on pairwise sequence alignment and identity calculation. PLoS One 9:e108277.

Parrella, G., Gognalons, P., Gebre-Selassiè, K., Vovlas, C., and Marchoux, G. 2003. An update of the host range of Tomato spotted wilt virus. J. Plant Pathol. 85:227-264.
Persley, D. M., Thomas, J. E., and Sharman, M. 2006. Tospoviruses - an Australian perspective. Australas. Plant Pathol. 35:161-180.

Sambrook, J., and Russell, D. W. 2001. Molecular Cloning: A Laboratory Manual, 3rd Ed. Cold Spring Harbor Laboratory Press, Cold Spring Harbor, NY.

Scholthof, K.-B. G., Adkins, S., Czosnek, H., Palukaitis, P., Jacquot, E., Hohn, T., Hohn, B., Saunders, K., Candresse, T., Ahlquist, P., Hemenway, C., and Foster, G. D. 2011. Top 10 plant viruses in molecular plant pathology. Mol. Plant Pathol. 12:938-954.

Srinivasan, K. G., Min, B. E., Ryu, K. H., Adkins, S., and Wong, S. M. 2005. Determination of complete nucleotide sequence of Hibiscus latent Singapore virus: Evidence for the presence of an internal poly(A) tract. Arch. Virol. 150:153-166.

Stresau, F. B. 1986. Florida, My Eden: Exotic and Native Plants for Use in Tropic and Subtropic Landscape. Florida Classics Library, Port Salerno, Florida.

Tamura, K., Stecher, G., Peterson, D., Filipski, A., and Kumar, S. 2013. MEGA6: Molecular Evolutionary Genetics Analysis version 6.0. Mol. Biol. Evol. 30: $2725-2729$

Thompson, J. D., Higgins, D. G., and Gibson, T. J. 1994. ClUSTAL W: Improving the sensitivity of progressive multiple sequence alignment through sequence weighting, position-specific gap penalties and weight matrix choice. Nucleic Acids Res. 22:4673-4680.

Wetter, C., and Conti, M. 1988. Pepper mild mottle virus. CMI/AAB Descriptions of Plant Viruses No. 330. 